\title{
Correction to: Construct validation of the shortened version of the behavior and instructional management scale within the Iranian context
}

\author{
Neda Soleimani ${ }^{1}$ - Daniel A. Sass ${ }^{2}$ - Alireza Ahmadi ${ }^{1}$ \\ ๑) Springer Science+Business Media, LLC, part of Springer Nature 2022
}

Correction to: Current Psychology (2021)

https://doi.org/10.1007/s12144-021-02266-6

The original version of this article unfortunately contained a mistake. The second author name has be corrected to Daniel A. Sass.

The original article has been corrected.

Publisher's note Springer Nature remains neutral with regard to jurisdictional claims in published maps and institutional affiliations.

The original article can be found online at https://doi. org/10.1007/s12144-021-02266-6.

Neda Soleimani

Soleimani_neda92@yahoo.com

Daniel A. Sass

daniel.sass@utsa.edu

Alireza Ahmadi

ar.ahmadi55@gmail.com

1 Department of foreign language and linguistic, Shiraz University, Eram Square, Shiraz, Iran

2 Department of Management Science, Department of Management Science and Statistics, University of Texas at San Antonio, One UTSA Circle, BB 4.06.08, TX 78249 San Antonio, USA 